\title{
74. レーザ手術装置の性能試験と評価法
}

西坂

剛*

最近国内外の各種レーザ手術装置が臨床的に 使用され始めた。一方手術室などで実際に装置 を使用する場合，装置導入前の仕様や性能は必 ずしも満足されない状態が発生していると思わ れる。この原因は装置の性能や試験結果が工場 や検查室など比較的条件の良い環境で行われて いることも一因であろう。一部装置の性能試験 は, 耐振性, 耐温度性など綮しい条件下で行わ れている。

臨床の場における装置の使用を考えるとき， 装置は常に一定の場所に固定されることは少な

* 東京農工大学保健管理センター
く，移動などによる光軸のずれ，手術中生体組 織より発生する媒煙，室内の埃などレーザ装置 の光学系に与える影響は大きい。 また電源供給 の安定性, 他装置よりの雑音障害の影響など電 気回路系の受ける問題もある.

これらのいくつかの問題に対し，各社におい て各様の対策が立てられているものの, ニーザ 側からみた仕様や性能は，使用条件が異るとい うことだけでは満足できない場合もあり得る. 性能試験法やその評価法については, 現在のと ころ，まだ一定した方法が提案されていない現 状において，発表においてはこれらの問題点に ついて考察し，それらの対処法について言及す る予定である。

\section{5.レーザ外科の 3 年間}

東海大学病院では 3 年間外科領域にレーザ外 科を 500 例以上施行した。使用したレーザ装置 は $\mathrm{CO}_{2}$ (Sharplan 791, El-op S-20, Coherent System-400), YAG (MBB), Argon (SpectraPhysics) である.

レーザ外科はいうまでもなく新しい医学の 分野で，最近 pioneer の時代を経て普及段階に 入ろうとしている．臨床の匛用範囲が広がるの

* 東海大学病院形成外科

$*^{2}$ 東海大学病院外科
は望ましいが，装置自体もまだ改善すべき点が 多く, User side よりの feed-back が必要と思 われるので，われわれの経験を報告したい.

今回は

1） $\mathrm{CO}_{2}$ レーザの適応と思われる疾患

2）われわれの開発した付属品および手術上 のテクニック

3）現在使用している装置の長所と短所

4）装置の改良すべき点

5）レーザ外科の展望

などを報告する。 